Artvin Çoruh Üniversitesi

Orman Fakültesi Dergisi

ISSN:2146-1880, e-ISSN: 2146-698X

YII: 2020, Cilt: 21, Sayı:2, Sayfa: 231-243

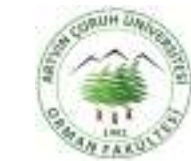

ofd.artvin.edu.tr
Artvin Coruh University

Journal of Forestry Faculty

ISSN:2146-1880, e-ISSN: 2146-698X

Year: 2020, Vol: 21, Issue:2, Pages: 231-243

@) (1)

\title{
Uluabat gölü ve çevresinde peyzaj karakter alanlarının belirlenerek sürdürülebilir alan kullanım stratejilerinin geliştirilmesi
}

\section{Developing sustainable land use strategies by determining landscape character areas in Uluabat lake and its surroundings}

\author{
Ayşenur AKBANA ${ }^{1}$ Yahya BULUT ${ }^{2}$ \\ ${ }^{1}$ Bingöl Üniversitesi, Ziraat Fakültesi, Peyzaj Mimarlığı Bölümü, Bingöl \\ ${ }^{2}$ Atatürk Üniversitesi, Mimarlık ve Tasarım Fakültesi, Peyzaj Mimarlığı Bölümü, Erzurum
}

Eser Bilgisi / Article Info

Araştırma makalesi / Research article

DOI: 10.17474/artvinofd.699170

Sorumlu yazar / Corresponding author Ayşenur AKBANA

e-mail: anurbektas@gmail.com

Geliş tarihi / Received

05.03.2020

Düzeltme tarihi / Received in revised form

08.05.2020

Kabul Tarihi / Accepted

16.05.2020

Elektronik erişim / Online available

17.07.2020

\section{Anahtar kelimeler:}

Peyzaj Karakter Analizi

Peyzaj Karakteri

Sürdürülebilirlik

Uluabat Gölü

\section{Keywords:}

Landscape Character Analysis

Landscape Character

Sustainability

Uluabat Lake

\begin{abstract}
Özet
Nüfus artışı, plansız kentleşme ve sanayi kaynaklı etkiler özellikle içerisinde bulunduğumuz yüzyılda, etkisini artan oranlarda hissettirmekte ve çevre üzerindeki baskısını arttırmaktadır. Bu baskılar peyzajların bozulmasına ve sulak alanlar gibi hassas ekosistemlere sahip alanlarda geri dönüşü mümkün olmayan kayıpların yaşanmasına neden olmaktadır. Bu kayıplar çevresel kaygıların ön plana çıkmasını ve bu doğrultuda uluslararası bir takım adımlar atılması gerekliliğini beraberinde getirmiştir. Peyzajların tanımlanması, korunması, yönetilmesi ve planlaması konularında uluslararası bir dil birliği geliştirilmesi amacıyla imzaya açılan Avrupa Peyzaj Sözleşmesi bu konuda atılan en önemli adımlardan biridir. APS gereğince; taraf ülkelerin tümü, peyzajlarını tanımlama, peyzaj karakter tiplerini belirleme, peyzajın değişim ve dönüşümünü izlemeyi taahhüt etmişlerdir. Bu çalışmada ülkemizin de taraf olduğu APS'den hareketle aynı zamanda uluslararası öneme sahip bir sulak alan olan Uluabat Gölü ve çevresinde planlama, yönetim, koruma ve sürdürülebilir alan kullanımına yönelik karar alma aşamalarında önemli bir yeri olan peyzaj karakter değerlendirme yöntemi kullanılmıştır. Çalışmada peyzaj karakter değerlendirme yönteminin bir aşaması olan peyzaj karakter analizindeki, peyzaj karakter tip ve alanlarının belirlenmesi aşamasına odaklanılmıştır. Çalışma alanının belirlenmesinde Ramsar tampon bölge sınırları dikkate alınmıştır. CBS tekniklerinden yararlanılan ve arazi çalışmalarıyla desteklenen çalışma sonucunda 229 adet peyzaj karakter tipi ve 7 adet peyzaj karakter alanı belirlenmiştir. Belirlenen her bir peyzaj karakter alanına ilişkin baskı unsurları ortaya konularak, sürdürülebilir alan kullanımına ilişkin öneriler geliştirilmiştir.
\end{abstract}

\begin{abstract}
The effects originating from population growth, unplanned urbanization and industry are increasingly being felt in the present century and enhancing their pressure on the environment. These pressures cause degradation of landscapes and irreversible losses in areas with sensitive ecosystems such as wetlands. These losses brought the environmental concerns to the forefront and the necessity to take steps in the international level accordingly. The European Landscape Convention, which was signed for the purpose of developing an international language association on the identification, conservation, management and planning of landscapes, is one of the most important steps taken in this regard. In accordance with ELC; all of the parties promised to identify their landscapes, to determine the landscape character types, and to monitor the change and transformation of the landscape. In this study, landscape character assessment method, which has an important role in decision making processes regarding planning, management, conservation and sustainable land use at Uluabat Lake and its surroundings, which is also a wetland with international importance, was used based on ELC, to which our country is one of the parties. The study focused on the determination of landscape type and character areas in landscape character analysis, which is a stage of landscape character assessment method. The Ramsar buffer zone limits were considered while determining the working area. As a result of the study which was supported by GIS techniques and land investigations, 229 landscape character types and 7 landscape character areas were identified. Suggestions for sustainable land use were developed by putting forth pressure elements on each landscape character area identified.
\end{abstract}

\section{GiRiş}

Arazi parçasının tanımlayıcı tüm özellikleri şeklinde ifade edilen peyzaj (Tülek ve Atik 2017), peyzajların tanımlanması, korunması, yönetimi ve planlaması konularında uluslararası düzeyde bir dil birliğinin oluşturulması amacıyla imzaya açılan Avrupa Peyzaj Sözleşmesi'nde; “insanlar tarafından algılandığı şekli ile 
özellikleri insan ve/veya doğal faktörlerin etkileşimi ve faaliyeti sonucu oluşan alanlar" olarak tanımlanmaktadır (Anonymous 2016).

Peyzaj karakteri ise bir peyzajı tek veya farklı kılan ya da diğer peyzajlardan bazı yönleriyle ayıran unsurların bütünüdür (Anonymous 2006, Çetinkaya ve Uzun 2014). Jeoloji, toprak, topografya, su varlığı, bitki örtüsü, arazi kullanım şekilleri ve yerleşimler gibi pek çok öğe peyzaj karakterinin oluşmasında etki gösterir. Her bir öğenin kendi içindeki çeşitlilik ve bunların bir araya gelme biçimleri bir alanın diğer bir alandan farklı olmasını sağlar ve o alana bir anlam yükler (Uzun 2018). Bu farklılıkların anlaşılması sosyo-ekonomik ve kültürel etmenlerle entegre edilerek yorumlanması ve değerlendirilmesi geleceğe yönelik planlama kararlarının alınabilmesi için son derece önemlidir.

Peyzaj karakter analizi, belirlenen bir alan ve ölçek dâhilinde doğal ve kültürel peyzaj bileşenlerinin analizi ve bunun sonucunda peyzaj karakter tipleri ve bunların alandaki dağılımlarının ortaya konulmasıdır (Kim and Pauleit 2007).

Tudor (2014)'e göre peyzaj karakter analizi beş temel prensibe dayanmaktadır;

•Tüm peyzajlar özgün bir karaktere sahiptir.

- Peyzaj karakter değerlendirmesi ulusal düzeyden, yerel bölge düzeyine kadar tüm ölçeklerde uygulanabilir.

- Peyzajın insanlar tarafından nasıl algılandığı ve deneyimlendiği de peyzaj karakter değerlendirmesinin önemli bir bileşenidir.

- Peyzaj karakter analizinin sonuçları, karar verme ve uygulama süreçleri için kanıt niteliğindedir.

- Peyzaj karakter analiziyle hem doğal hem de sosyokültürel değişkenlerin etkisiyle şekillenen peyzajın bütüncül açıdan değerlendirilmesi sağlanmaktadır.

1990'lı yıllardan itibaren birçok ülkeden önce İngiltere ve İskoçya'da peyzajların tanımlanması ve peyzaj karakter analizine ilişkin yöntemler geliştirilmiştir (Herlin 2016). Örneğin İskoçya'da 1994-1999 yılları arasında bölgesel ölçekte otuz farklı alanda, doğal mirasın korunması ve planlama politikalarının oluşturulmasına katkı sağlamak amacıyla peyzaj karakter değerlendirmesi yaygın olarak kullanılmıştır (Anonymous 2018). Peyzaj karakter analizi İngiltere'de peyzaj değişiminin izlenmesi ve peyzaj yönetimi için bir çerçeve olarak yerleşmiş, bu yönüyle çağdaş planlama uygulamalarına dayanak noktası olmuştur (Scott 2002). Avrupa Birligi üye ve aday ülkelerince 1996 yılında Pan-Avrupa Biyolojik ve Peyzaj Çesitliliği Stratejisi ve 2000 yılında Avrupa Peyzaj Sözlesmesi ile peyzaj karakter tiplerinin belirlenmesi peyzajların korunmasında yasal gereklilik olarak kabul edilmiştir (Görmüş 2012).

Türkiye, Avrupa Peyzaj Sözleşmesi'ne 2000 yılında taraf olmuş ve sözleşme 27.07.2003 tarihinde resmi gazetede yayınlanarak yürürlüğe konulmuştur (Anonim 2017). APS'ye taraf olunmasıyla birlikte ülkemizde de peyzajların tanımlanmasına, peyzaj karakter analizine ilişkin farklı ölçeklerde çalışmalar gerçekleştirilmiştir. Uzun ve ark. (2012), Görmüş (2012), Şahin ve ark. (2014), Atik ve ark. (2015), Demir ve Demirel (2016), Tülek ve Atik (2017), Koç (2017), Tırnakçı ve Özer (2018), Turgut ve Tırnakçı (2020)'nın çalışmaları bu konuda ortaya konulan önemli çalışmalar arasındadır.

Günümüzde yerel planlama, yerleşim alanlarının belirlenmesi, ekonomik değerlendirme ve stratejilerin geliştirilmesi, rekreasyon ve turizm stratejileri, yenilenebilir enerji stratejileri, kıyı karakterini korumak için plan ve stratejilerin geliştirilmesi yanında, biyoçeşitlilik yönetimi, restorasyon ve iyileştirme çalışmaları, arazi kullanım ve yönetim planlarııı oluşturulması, ÇED, sürdürülebilirlik değerlendirmesi, duyarlılık ve kapasite çalışmaları, görsel peyzaj etkisinin değerlendirilmesi gibi pek çok çalışma konusunda peyzaj karakter değerlendirmesinden yararlanılmaktadır (Tudor 2014).

Ülkemizin taraf olduğu bir diğer uluslararası sözleşme ise "Uluslararası Öneme Sahip Sulak Alanların Korunması Hakkında Sözleşme" (Ramsar)'dir. Ramsar Sözleşmesi imzaya açıldığı tarih itibariyle, doğal kaynakların korunması ve sürdürülebilir kullanımını hedefleyen ilk, yalnızca tek bir habitat tipini korumaya odaklanan ve bu 
doğrultuda uygulamaya konulan tek uluslararası sözleşme niteliği taşımaktadır (Hızlı ve ark. 2013). Ramsar sözleşmesinin misyonu; tüm dünyada sürdürülebilir kalkınmanın gerçekleştirebilmesi için yerel, bölgesel, ulusal faaliyetler ve uluslararası işbirlikleri sağlanarak tüm dünyada sulak alanların korunması ve akılcı kullanımı olarak belirtilmektedir. Sözleşmeye taraf olan ve 1994 yılı itibariyle ülkemizin de aralarında bulunduğu 169 ülke ulusal plan, politika, mevzuat, yönetim ve halkın bilinçlendirilmesi yoluyla sınırları içerisinde yer alan sulak alanların ve su kaynaklarının akılc kullanımını taahhüt etmektedirler (Anonymous 2018a). Ramsar'da belirtilen kriterler dikkate alınarak, ülkemizde günümüze kadar, biri çalışma alanını oluşturan Uluabat Gölü olmak üzere toplam 14 uluslararası öneme sahip sulak alan tescillenmiştir (Anonim 2018).

Ülkemizin de taraf olduğu APS'den hareketle aynı zamanda Ramsar alanı olan Uluabat Gölü ve çevresinde gerçekleştirilen bu çalışmayla; alanın karakterini şekillendiren doğal ve kültürel peyzaj bileşenlerinin belirlenmesi, peyzaj karakter analizinin bir parçası olan, peyzaj karakter tipleri ile peyzaj karakter alanlarının belirlenmesi ve haritalandırılması, peyzaj karakterindeki değişimin izlenebilmesi için bir veri tabanı oluşturulması ve sürdürülebilir alan kullanımına ilişkin öneriler geliştirilmesi amaçlanmaktadır.

\section{MATERYAL VE YÖNTEM}

\section{Materyal}

Çalışma alanı, Bursa iline bağlı Nilüfer, Karacabey ve Mustafakemalpaşa ilçe sınırlarının kesişimi içerisinde yer almakta olan Uluabat Gölü Ramsar Tampon Bölgesi'dir. Alan, aynı zamanda Bursa, Kütahya, Balıkesir illerinin büyük çoğunluğu ile Bilecik ilinin çok az bir kısmını kapsayan ve toplamda 10756 km$^{2}$ alan kaplayan Susurluk Havzası içerisinde bulunmaktadır (Anonim 2007). Çalışma alanı sınırları içerisinde bulunan Uluabat Gölü, Bursa kent merkezine $34 \mathrm{~km}$ mesafede olup, Bursa-izmir karayolunun güneyindedir. Çalışma alanı yaklaşık olarak $480 \mathrm{~km}^{2}$ alansal büyüklüğe sahiptir.

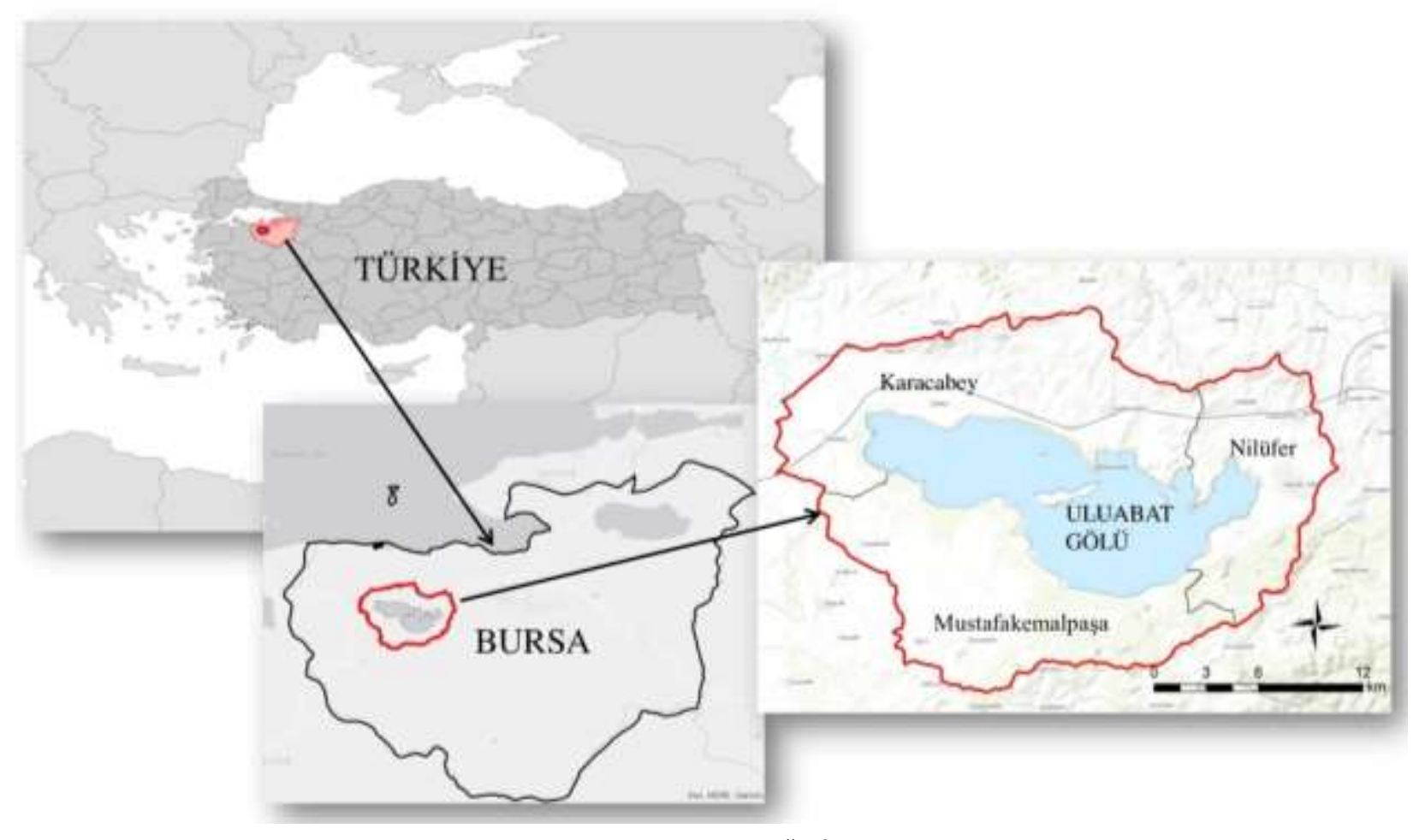

Şekil 1. Çalışma alanının coğrafi konumu

Çalışma alanının, Uluabat Gölü’nü de kapsayan 199 km²' lik kısmı Ramsar alanı olarak tanımlanırken, bunun dışında kalan $281 \mathrm{~km}^{2}$ alan Ramsar tampon bölge olarak tanımlanmaktadır. Uluabat Gölü Ramsar alanı olmasının yanında, aynı zamanda 2000 yılında, uluslararası bir sivil toplum kuruluşları ortaklığı projesi olan "Yaşayan Göller" 
(Living Lakes) ağına dâhil edilmiştir (Anonim 2011). Çalışma alanını oluşturan tampon bölge sınırları içerinde köy (mahalle) statüsünde toplam 22 yerleşim alanı bulunmaktadır.

Uluabat Gölü Ramsar alanı, nesli tehlike altında ve hassas türler barındırması, memeli ve kuş türleri açısından biyolojik döngülerin kritik safhalarına önemli bir alan olması, düzenli olarak yüksek sayıda su kuşu barındırması ve balıklar için önemli bir yaşam alanı olması açısından önem taşımaktadır. Bu özellikleriyle 9 uluslararası öneme sahip sulak alan kriterinden 4'ünü sağlamaktadır (Anonim 2013).

Çalışma alanı sınırlarının belirlenmesinde Uluabat Gölü tampon bölge koruma sınırları dikkate alınmış, peyzaj karakter tip ve alanlarının belirlenmesinde; 1/25000 ölçekli çalışma alanına ilişkin eş-yükselti haritaları, 1/25000 ölçekli çalışma alanına dair büyük toprak grupları haritası, 1/25000 ölçekli çalışma alanına dair arazi kullanım şekilleri haritası, 1/25000 ölçekli çalışma alanına ilişkin jeoloji ve vejetasyon haritalarından yararlanılmıştır.

\section{Yöntem}

Yerel düzeyde gerçekleştirilen bu çalışmada; Swanwick (2002), Uzun ve ark. (2012), Görmüş ve Oğuz (2013), Şahin ve ark. (2014), Atik ve ark. (2015), Demir ve Demirel (2016), Tırnakçı ve Özer (2018)'in peyzaj karakterine ilişkin çalışmaları incelenmiş, çalışmalarında kullandıkları yöntemler temel alınarak çalışma alanına uyarlanmıştır. Çalışma, büro ve arazi çalışmaları olmak üzere iki temel basamaktan oluşmaktadır. Büro çalışmaları kapsamında alana ilişkin 1/25000 ölçekli topoğrafik haritadan yararlanılarak yükseklik sınıfları haritası oluşturulmuş, eğim-bakı analizleri gerçekleştirilmiştir. Peyzaj karakter tiplerinin tespiti amacıyla çakıştırmada kullanılacak 1/25000 ölçekli topoğrafya, vejetasyon, arazi kullanımı, toprak grupları ve jeolojik formasyon haritaları ArcGIS 10.2 programı kullanılarak poligon verilere dönüştürülmüş, her bir harita için kendi içinde kodlama yapılarak oluşturulmuştur.

\section{PEYZAJ KARAKTER TIPLERININ BELIRLENMESINDE KULLANILAN VERILER VE SINIFLANDIRILMASI}

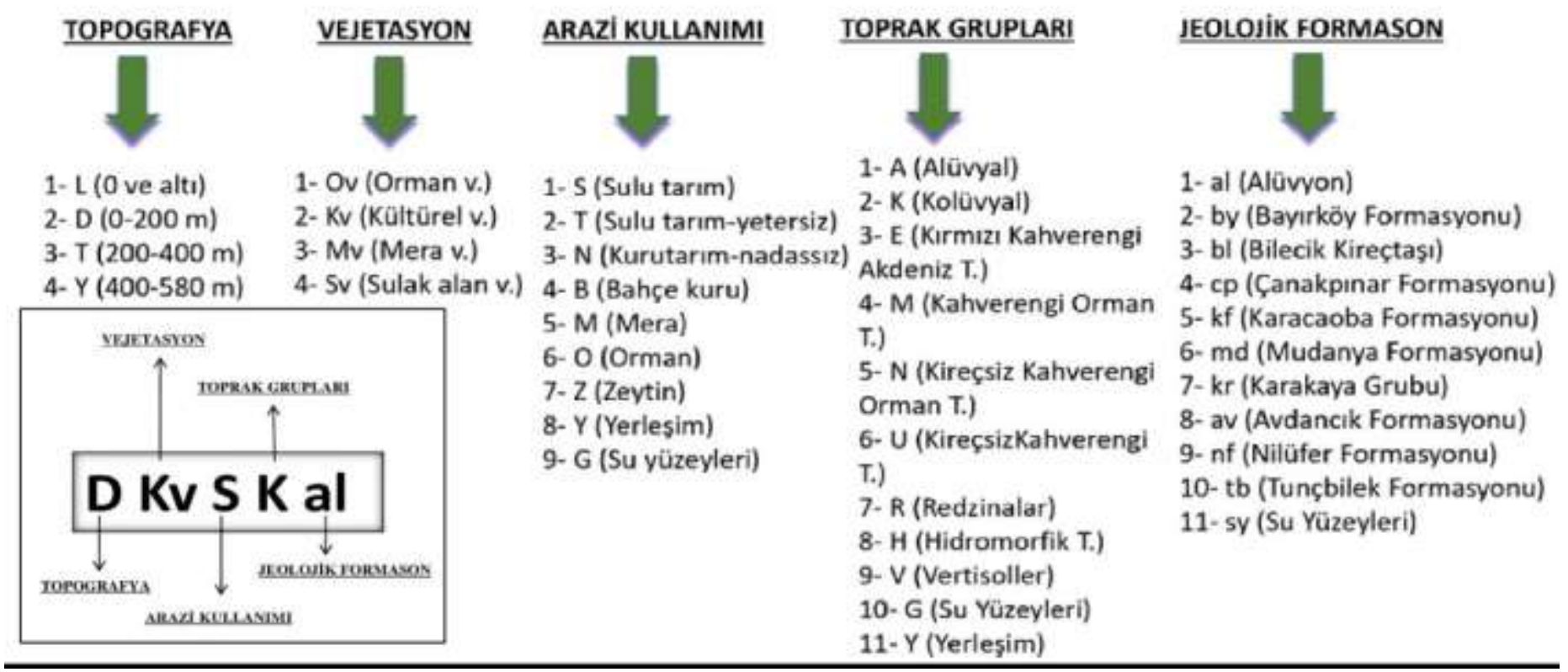

Şekil 2. Peyzaj karakter tiplerinin belirlenmesinde kullanılan veriler ve sınıflandırılması

Örneğin, DKvSKal olarak ifade edilen peyzaj karakter tipinin açılımı 0-200 m. yükseklik grubunda, kültürel vejetasyon sınıfında, sulu tarım yapılan, kolüvyal topraklara sahip, jeolojik formasyon olarak alüvyon özellikteki peyzaj karakter tipi olarak tanımlanmaktadır. 
Arazi çalışmaları 2014-2017 yılları arasında çalışma alanı içerisindeki 22 adet yerleşimi kapsayacak şekilde belirlenen rotalarda, yılın farklı dönemlerinde yürütülmüştür. $\quad$ 20.06.2014-21.06.2014, 21.09.2014, 11.06.2015-12.06.2015, 20.06.2015, 28.11.2015, 14.07.2016-15.07.2016, $\quad$ 11.04.2017-12.04.2017 tarihlerinde yapılan arazi çalışmaları kapsamında, alanın sahip olduğu doğal ve kültürel yapıya ilişkin gözlem ve incelemelerde bulunulmuş, yöre halkıyla yapılan sözlü görüşmeler ile alan hakkında bilgiler toplanmış, arazi sörveyi gerçekleştirilmiştir.

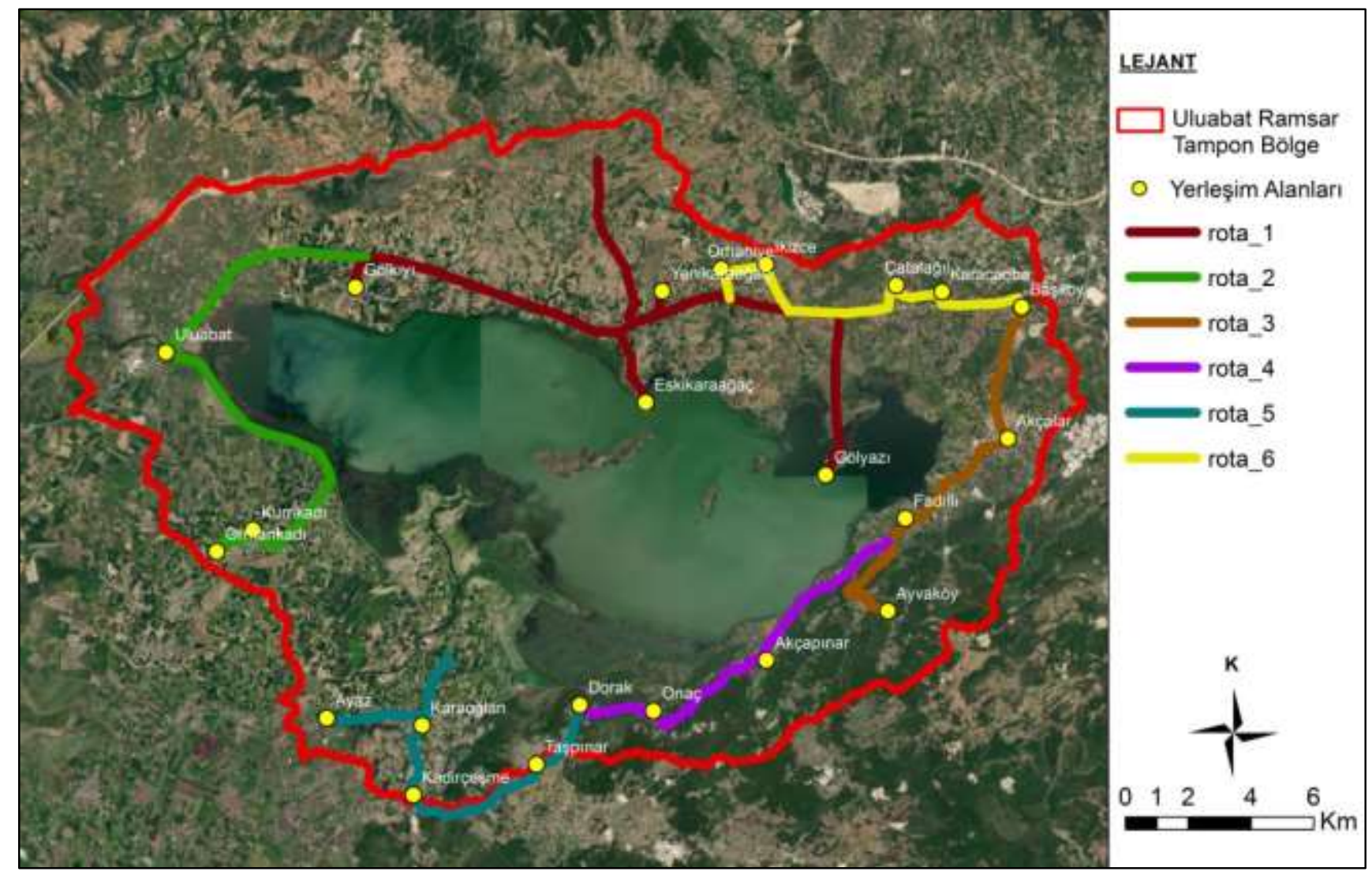

Şekil 3. Çalışma alanı içerisindeki yerleşim alanları ve arazi çalışmaları sırasında izlenen rotalar

Peyzaj karakter tiplerini belirlemede kullanılmak üzere oluşturulan topografya, vejetasyon, arazi kullanımı, toprak grupları, jeolojik formasyon haritaları CBS ortamında çakıştırılmış, parametrik yöntem kullanılarak peyzaj karakter tipleri haritası elde edilmiştir. Peyzaj karakter tiplerinin tespitinde kullanılan veriler, sosyoekonomik ve sosyo-kültürel yapıya ilişkin bilgiler ile arazi sörveyi doğrultusunda peyzaj karakter alanları belirlenmiş ve haritalandırılmıştır.

Arazi çalışmaları sırasında alanın sahip olduğu doğal ve kültürel yapıya ilişkin gözlem ve incelemeler, yöre halkıyla yapılan sözlü görüşmeler ve literatür taramaları sonucunda alanda, peyzajlar üzerinde baskı oluşturan etmenler ile alanının potansiyel değerleri saptanmıştır. Büro ve arazi çalışmaları sonucunda elde edilen bulgular değerlendirilerek belirlenen peyzaj karakter alanlarının sürdürülebilir kullanımına ilişkin stratejiler geliştirilmiştir.

\section{BULGULAR}

Alan içerisinde 4 sınıfa ayrılan yükseklik verisi, 4 vejetasyon sınıfı, 9 tip arazi kullanım şekli, 11 büyük toprak grubu ve 11 sınıftan oluşan jeolojik formasyon haritaları ArcGIS 10.2 programı kullanılarak poligon verilere dönüştürülüp, analiz edilerek 229 peyzaj karakter tipi elde edilmiştir. 


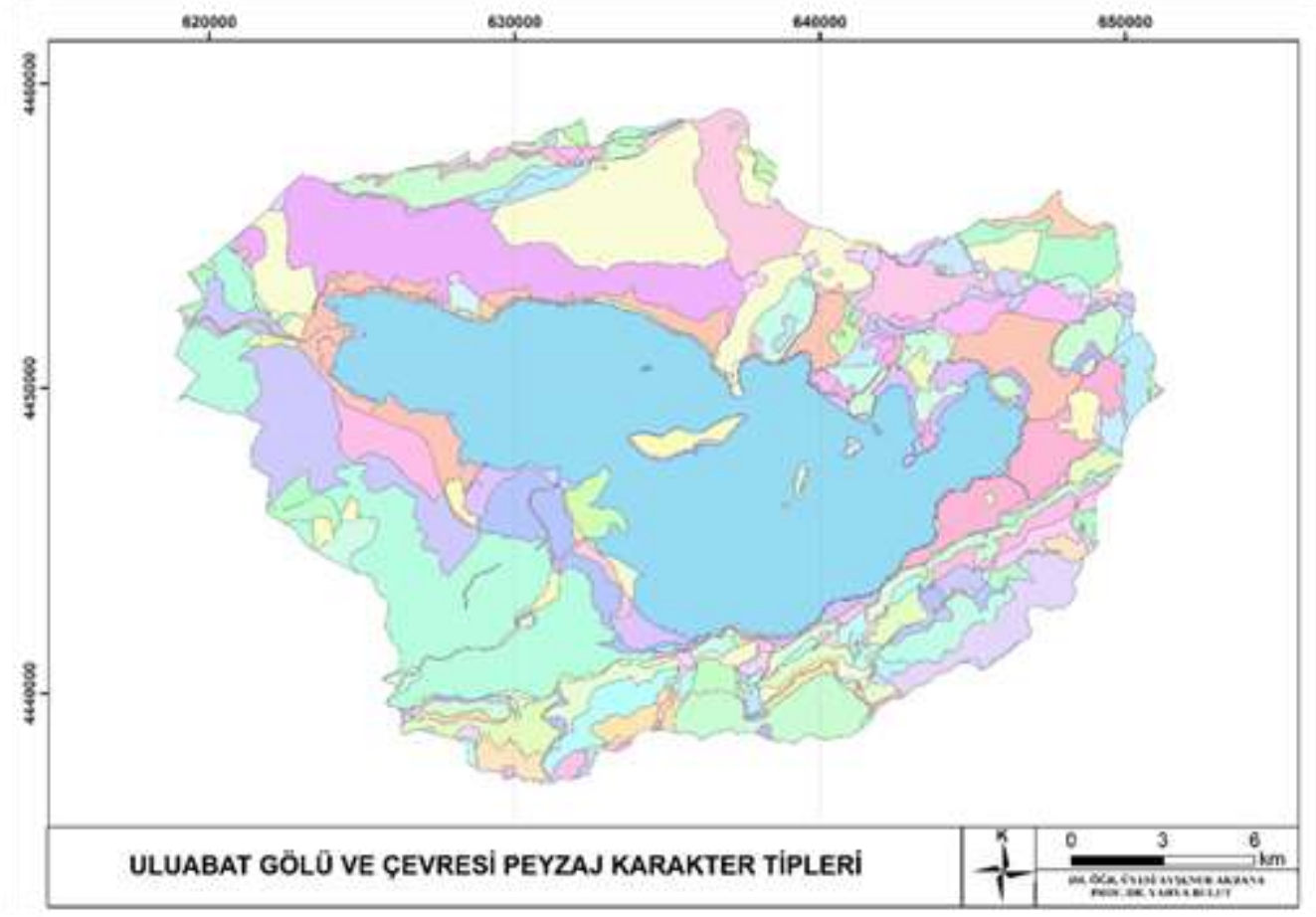

Şekil 4. Çalışma alanına ilişkin peyzaj karakter tipleri haritası

\begin{tabular}{|c|c|c|c|c|c|c|c|}
\hline \multicolumn{8}{|c|}{ ULUABAT GÖLÕ VE ÇEVRESI PEYZAJ KARAKTER TIPLERİ LEJANTI } \\
\hline OKVEEOS & Dxwars & Dovisver & Do,fEal & Dsvocime & IMMEED & TKSWUE: & Tovefolo \\
\hline oxveremo & DARNoves & onvesves & DONEG & OSHGCAY & IMtMatal & TKanuby & Toweres \\
\hline oxrocal & Downent & okvsuns & DOAfES & cosisher & IMunitsy & Trowues & Torfust \\
\hline CKNGKCOI & Daxwovind & OKvsVme & DOffep & IKragal & LMarval & Thowuat & rocand \\
\hline CKunaal & Doxwivent & DokvSWur & DOffEme & 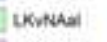 & LOAFES & Thoneunt & Tocarby \\
\hline OKNAEA & ockisnai & okrsya & Dorfent & LKWhited & LOFfEsy & TKMNVW: & Wunakor \\
\hline CXNNES & DKISAAI & DokrsYmd & DOAFEY & uknoery & LOVFMai & Thanves & YKunMes \\
\hline OKMNEDY & DXVISAms & OKvTKaE & Donfett & UKNotsy & LOANwy & TKANVme & rewalley \\
\hline CKwNETS & Dovisasy & DKuTnes & Dorfual & unvseal & Lorfual & namra & Wrownel \\
\hline DKNNHE & Dorssuth & OKvTKsy & Dorfind & LKrsend & losfued & nkmoy & wrwovar \\
\hline Oxuntey & Dnvelal & OKYYEA & Doffuby & LKvisay & Lonoval & thmrmm & mamroy \\
\hline Cxunitsr & Darised & DKVYTEAY & DOVFMr & unsed & Lovatby & Tkirre & roufEar \\
\hline Cxuneral & owvsent & OKvYKMnd & Dowlusy & Laveskal & Lovoley & trumused & vowfes: \\
\hline CXuntert & DKVSEAY & Dkvrye & Dovfunt & unsosy & ISvGeal & TMNount & Yosfmer \\
\hline oxineviby & DEvSGal & okima & DONARE & IKvSAal & isvocal & TONEar & Yownes \\
\hline CKunisy & DKVISKat & okrme & Dorfual & UKsAms & IS.GOD & TONFES & YOAfMor \\
\hline DOANNES & Dxnskd & OKurmo & corfued & UKSARAY & ISvocosy & Touftoy & rownos \\
\hline oxwines & Danskey & Dosuryind & Dorfules & unsuat & LSVGGm & TONFEMA & YOAfNav \\
\hline CXINRaI & DKvoskme & okvryoy & Dowfust & LKvsume & IS.GGsy & TOWFent & Yownes \\
\hline OXWNRE & DKVSKSYY & okvrnt & Dorfund & UKrsval & Truned & TONFE & YOAFEYY \\
\hline OKuNFor & oxvșal & Drvizear & Donfuny & Lursyma & Trusul & TOAfus & rowner \\
\hline cixnernd & DKvispend & oumeal & conval & unvtikal & Truavery & TOFus & rowoear \\
\hline CKWNRE & Dxuspesy & OUNEeA & Dovfund & Uxvitosy & Trwaser & Toxfuby & rovers \\
\hline OXXNua & Dkrsual & Ouwhitsy & Dovoul & unMeds & Thuevar & Todfule & rovomar \\
\hline CKunU: & Dersuad & DUMURE & Dorousa & LKmral & Thuevel & To.fNe & Yovoner \\
\hline CKNAUCp & OKVSUCD & Demave & Doveatby & uxmes & Thuswir & TONALEV & rowousy \\
\hline comonet & Dikvsuat & CoMMiunet & Dovcantsy & ikmiry & TKMEAS & Tonflest & \\
\hline CXXNilund & oxvsume & oMumvat & DSncos & UKVEEA & Thushend & towfley & \\
\hline onenval & Cx:Sval & ontunvind & osicad & uxwzey & TRWAG & romer & \\
\hline
\end{tabular}

Şekil 5. Çalışma alanına ilişkin peyzaj karakter tipleri lejantı

Peyzaj karakter alanları; coğrafi özellikler başta olmak üzere arazi kullanımı, tarihsel, kültürel özellikler, doğal yapı ve görsel karakterleri ile diğerlerinden ayrılan alanları ifade etmektedir (Martin 2006, Atik ve ark. 2015). Belirli 
tutarlılıkları bulunan farklı peyzaj karakter tipleri bir araya gelerek özgün peyzaj karakter alanlarını oluşturur.

Çalışma kapsamında, çalışma alanı içerisinde peyzaj karakter tiplerinin belirlenmesinde kullanılan; yükseklik, vejetasyon, arazi kullanım şekilleri, toprak ve jeoloji verileri yanında alana ilişkin sosyal faktörler, kültürel peyzaj değerleri ve arazi sörveyi doğrultusunda 7 farklı peyzaj karakter alanı belirlenmiştir.

Çalışma alanında belirlenen peyzaj karakter alanları;
- Çatalağıl Tarımsal Yoğunluklu Peyzaj Karakter Alanı

- Uluabat Sulak Alan Peyzaj Karakter Alanı

- Dorak Mevkii Fundalık-Ormanlık Yoğunluklu Peyzaj Karakter Alanı

- Canbaz Fundalık Yoğunluklu Peyzaj Karakter Alanı

- Akçalar Kentsel-Endüstriyel Baskı Yoğunluklu Peyzaj Karakter Alanı

- Uluabat Adalar Peyzaj Karakter Alanı

- Gölyazı Tarihsel-Arkeolojik Yoğunluklu Peyzaj Karakter Alanı

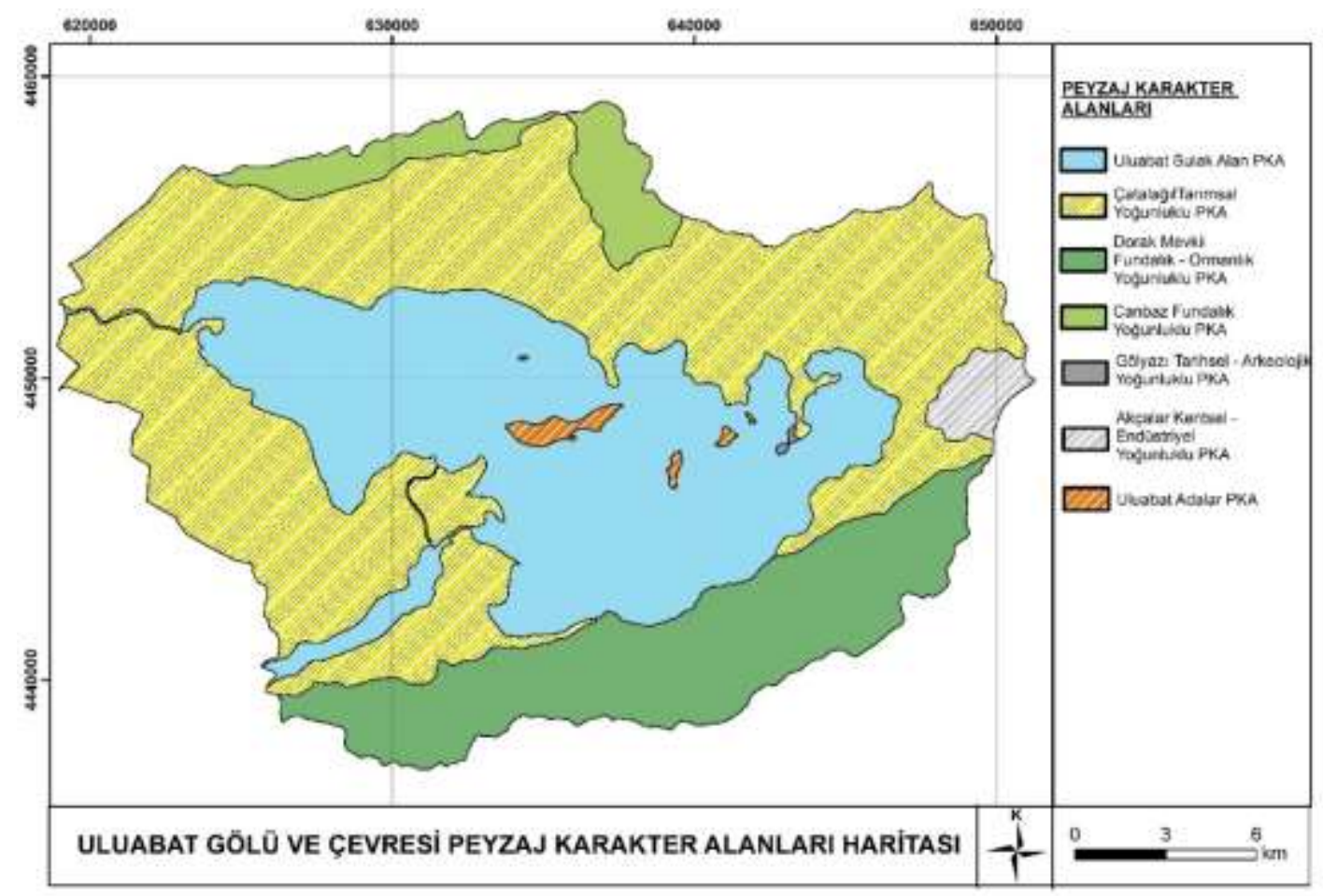

Şekil 6. Çalışma alanına ilişkin peyzaj karakter alanları haritası

Çizelge 1. Peyzaj karakter alanlarının tanımlanması

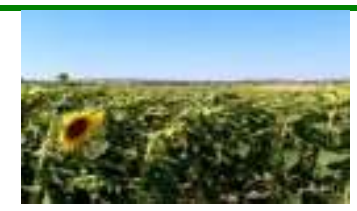

Çatalağıl Tarımsal Yoğunluklu PKA

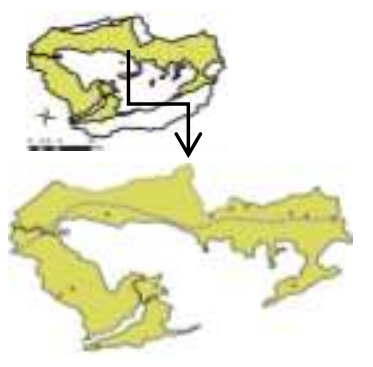

Çalışma alanının Güneydoğu kesimi dışında Uluabat Gölü’nü çevreleyen tarımsal üretimin yoğunlukta olduğu alanlar Çatalağıl Tarımsal Yoğunluklu Peyzaj Karakter Alanı olarak belirlenmiştir. Çatalağıl Tarımsal Yoğunluklu PKA 22649 ha ile çalışma alanının \% 47.15'ini oluşturmaktadır. Alanın baskın peyzaj karakter tipleri; DKvSAal, DKvSVmd, DKvNVmd, LKvSAal'dir.

Alüvyal ve vertisollerin ağırlıkta olduğu alanın büyük çoğunluğunu, arazi kullanım kabiliyeti açısından ağırlıklı olarak I, II ve III. sınıf araziler oluşturmaktadır. Alüvyon ve Mudanya formasyonunun yoğunlukta olduğu alanda yükseklik çoğunlukla 0- 200 m aralığındadır. Yaygın olarak sulu tarım yapılmaktadır Çatalağıl Tarımsal Yoğunluklu PKA içerisinde Çatalağıl, Fadılı, Başköy, Karacaoba, Ikizce, Orhaniye, Eskikaraağaç, Yenikaraağaç, Gölkıyı, Uluabat, Kumkadı, Ormankadı ve Ayaz olmak üzere 13 yerleşim alanı yer almaktadır ve bu yerleşimlerin toplam nüfusu $5506^{\prime}$ dır. 
Çizelge 1 (Devamı).Peyzaj karakter alanlarının tanımlanması

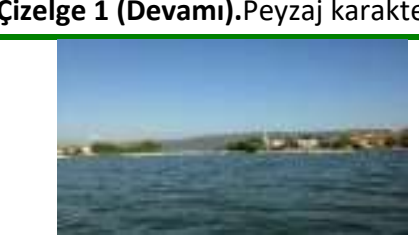

Uluabat Sulak Alan PKA
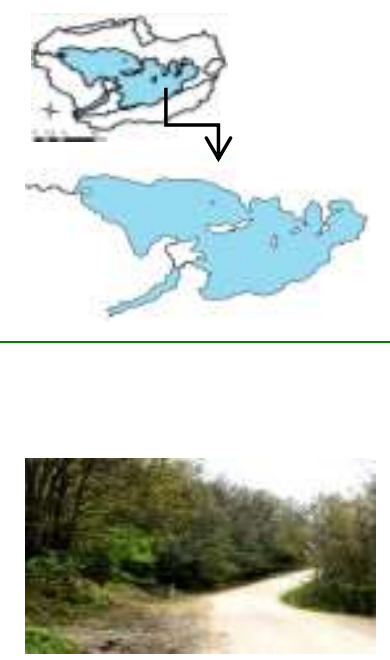

Dorak Mevkii Fundalık-Ormanlık

Yoğunluklu PKA
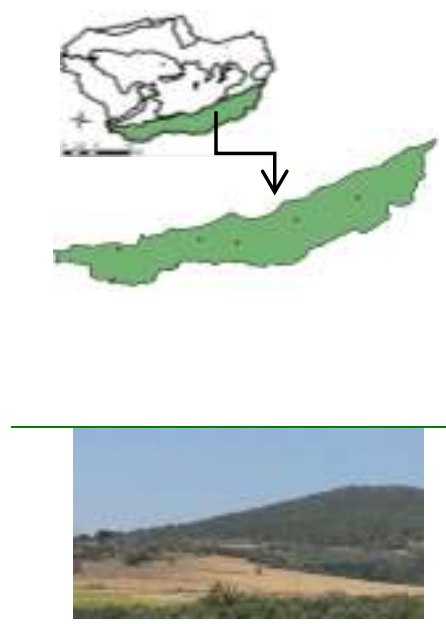

Canbaz Fundalık Yoğunluklu

PKA

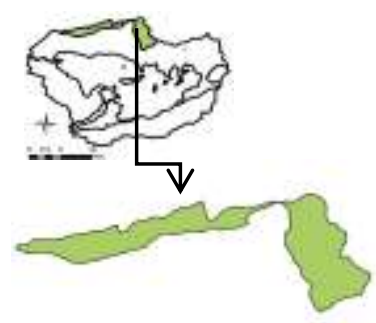

Uluabat Gölü, gölü besleyen en önemli kaynak olan ve alanın batı kesimlerinde yer alan Mustafakemalpaşa Çayı ile alanın kuzeybatı kesiminde genel olarak gölden su boşaltımı sağlayan Uluabat Deresi'nden oluşan kesim Uluabat Sulak Alan Peyzaj Karakter Alanı olarak belirlenmiştir. Uluabat Sulak Alan PKA 14945 ha ile çalışma alanının \% 31.1'ini oluşturmaktadır. Alanın baskın peyzaj karakter tipi LSvGGsy'dir.

Türkiye'nin en geniş nilüfer yataklarına sahip gölü olarak tanımlanan Uluabat Gölü’nde beyaz nilüfer (Nympha alba), gölün kuzeydoğu kıyılarında ve Mustafakemalpaşa Çayı'nın göle giriş ağzında çok geniş alanları kaplamaktadır. Göl, pek çok balık türü ve özellikle su kuşları için büyük önem taşımaktadır.

Çalışma alanının Güney- Güneydoğu sınırını ve alanın en yüksek kesimlerini oluşturan fundalık ve ormanlıkların yoğunlukta olduğu alan Dorak Mevkii Fundalık-Ormanlık Yoğunluklu Peyzaj Karakter Alanı olarak belirlenmiştir. Dorak Mevkii Fundalık-Ormanlık Yoğunluklu PKA 7292 ha ile çalışma alanının \% 15.2'sini oluşturmaktadır. Alanın baskın peyzaj karakter tipleri; YOvOMbl, YOvFNav, TOvFMbl, YOvFNbl'dir.

Kahverengi orman toprakları ile kireçsiz kahverengi orman topraklarının ağılıkta olduğu alanın büyük çoğunluğunu arazi kullanım kabiliyeti açısından VII. sınıf araziler oluşturmaktadır. Bilecik kireçtaşı ve Avdancık formasyonunun ağırlıkta olduğu alanda yükseklik çoğunlukla 200 m’nin üstünde değerlere sahip olup 580 m yüksekliğe kadar ulaşmaktadır.

Dorak Mevkii Fundalık-Ormanlık Yoğunluklu PKA içerisinde Dorak, Ayvaköy, Akçapınar, Onaç, Taşpınar, Karaoğlan ve Kadirçeşme olmak üzere 6 yerleşim alanı yer almaktadır ve bu yerleşimlerin toplam nüfusu 2843'tür.

Meşe (Quercus sp.) türleri başta olmak üzere, erguvan (Cercis siliquastrum), defne (Laurus nobilis), sakız ağacı (Pistacia terebinthus), karaçalı (Paliurus spina), böğürtlen (Rubus sp.), kuş üzümü (Rubus discolor) kuşburnu (Rosa canina), alıç (Crataegus monogyna), ağaç fundası (Erica arborea), kurtbağıı (Ligustrum vulgare) gibi geniş yapraklı türler yaygın olarak görülmektedir.

Çalışma alanının Kuzey sınırında yer alan, yer yer tarımsal alanların görüldüğü çoğunlukla fundalıklarla kaplı alan Canbaz Fundalık Yoğunluklu Peyzaj Karakter Alanı olarak belirlenmiştir. Canbaz Fundalık Yoğunluklu PKA 2165 ha ile çalışma alanının \% 4.5'ini oluşturmaktadır.

Alanın baskın peyzaj karakter tipleri; DOvFVmd, DOvFEbl, TOvFEbl'dir.

Canbaz Fundalık Yoğunluklu PKA içerisinde yerleşim alanı bulunmamaktadır. Vertisoller ile kırmızı kahverengi akdeniz topraklarının ağırlıkta olduğu alanın büyük çoğunluğunu arazi kullanım kabiliyeti açısından III. ve VII. sınıf araziler oluşturmaktadır. Mudanya formasyonu ve Bilecik kireçtaşının ağırlıkta olduğu çalışma alanında yükseklik 250 m’ye kadar ulaşmaktadır.

Meşe (Quercus sp.) başta olmak üzere geniş yapraklı çalı türleri alanın bitki örtüsünü oluşturmaktadır. 
Çizelge 1 (Devamı).Peyzaj karakter alanlarının tanımlanması

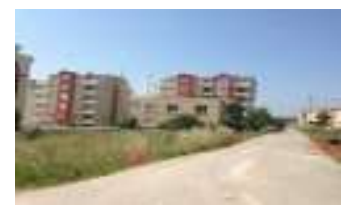

Akçalar Kentsel- Endüstriyel

Yoğunluklu PKA
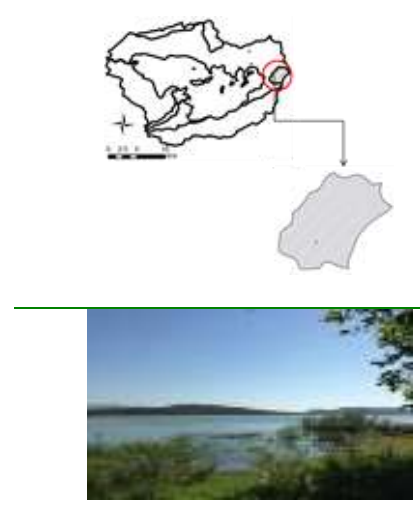

Uluabat Adalar PKA
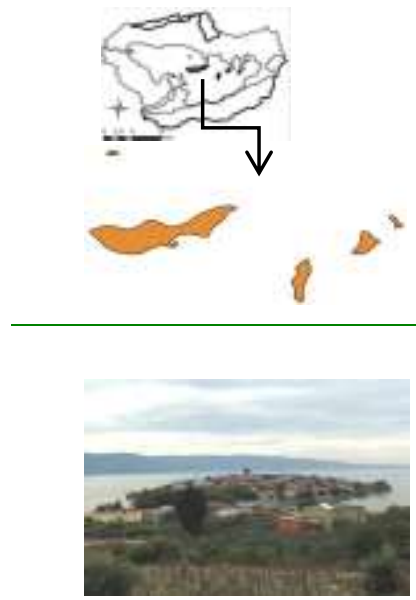

Gölyazı Tarihsel-Arkeolojik

Yoğunluklu PKA

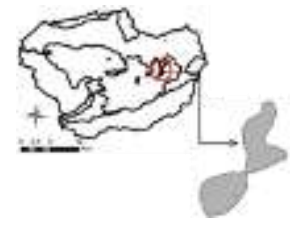

Çalışma alanının batı kesiminde yer alan ve kırsal dokudan uzaklaşarak gerek sanayi gerekse kente özgü kullanım biçimlerinin yoğunluklu olarak görüldüğü alan Akçalar Kentsel- Endüstriyel Yoğunluklu Peyzaj Karakter Alanı olarak belirlenmiştir. Akçalar Kentsel -Endüstriyel Yoğunluklu PKA 665 ha ile çalışma alanının \% 1.4 'ünü oluşturmaktadır.

Alanın baskın peyzaj karakter tipleri; DKvYYal, DKvSKal, DKvNEmd, DKvSKmd'dir.

Kırmızı kahverengi akdeniz toprakları ile kolüvyallerin ağırıkta olduğu alanın büyük çoğunluğunu arazi kullanım kabiliyeti açısından II ve III. sınıf araziler oluşturmaktadır. Alüvyon ve Mudanya formasyonunun yoğunlukta olduğu alanda, yükseklik 200 m’lere ulaşmakta, çok az bir alan kaplamakla birlikte yüksek kesimlerde fundalıklarda görülmektedir.

Akçalar Kentsel - Endüstriyel Baskı Yoğunluklu PKA içerisinde 3552 nüfusla, çalışma alanının en yüksek nüfuslu yerleşimi olan Akçalar yerleşim alanı bulunmaktadır.

Uluabat Adalar Peyzaj Karakter Alanı olarak belirlenen beş ada toplam 280 ha ile çalışma alanının yaklaşık \% 0.6 'sını oluşturmaktadır. Halilbey Adası 213 ha, Manastır Adası 34 ha, Terzioğlu Adası 24 ha, Arifmolla Adası 5 ha ve Bulut Adası 2 ha büyüklüktedir.

Alanın baskın peyzaj karakter tipleri; DKvZEbl, DOvFEbl'dir.

Kırmızı kahverengi akdeniz topraklarının görüldüğü adalar, arazi kullanım kabiliyeti açısından IV. ve VI. sınıf arazilerden oluşmaktadır. Yüksekliğin 90 m’ye kadar ulaştığı Halilbey Adası da dahil olmak üzere tüm adalarda jeolojik yapı Bilecik kireçtaşından oluşmaktadır.

Uluabat Adalar PKA içerisinde yerleşim alanı yer almamaktadır. Halilbey ve Manastır adalarının neredeyse tamamında zeytin yetiştiriciliği yapılmaktadır. Diğer adalarda doğal sazlık ve başta söğüt (Salix sp.) türleri olmak üzere çalıık ve fundalıklar görülmektedir.

Çalışma alanında Antik Çağ’a ait kalıntılar ile Osmanlı dönemine ait eserlerin yoğun olarak bulunduğu ve bu yönleriyle farklılaşan Gölyazı yerleşim alanı çevresi Gölyazı Tarihsel-Arkeolojik Yoğunluklu Peyzaj Karakter Alanı olarak belirlenmiştir. Gölyazı Tarihsel-Arkeolojik Yoğunluklu PKA 24 ha ile çalışma alanının \% 0.05 'ini oluşturmaktadır.

Alanın baskın peyzaj karakter tipleri; DKvYYbl, DKvYEbl'dir.

Yerleşim alanı dışında kırmızı kahverengi akdeniz topraklarının görüldüğü ve Bilecik kireçtaşının ağılıkta olduğu alanda yükseklik 40 m’ye kadar ulaşmaktadır.

Gölyazı Tarihsel-Arkeolojik Yoğunluklu PKA'yı oluşturan Gölyazı yerleşiminin nüfusu 1419'dur.

1998 yılında Anıtlar Yüksek Kurulu tarafından Kentsel Arkeolojik Sit Alanı olarak tescillenmiş olan Gölyazı'da; 19. ve 20. yüzyıl Yunan klasik mimarisini yansıtan Aziz Panteleimon Kilisesi, Yunan - Roma dönemlerine ait farklı mezar tiplerini barındıran nekropol, tiyatro ve stadyum kalıntıları, Osmanlı dönemine ait hamam, yel değirmeni ve Gölyazı Camii ile 87 sivil mimarlık örneği ve 7 anıt ağaç bulunmaktadır.
Belirlenen peyzaj karakter alanları içerisinde çoğunlukla antropojen etkilerden kaynaklanan peyzajın yapı ve fonksiyonunu etkileyerek, peyzaj karakter alanları üzerinde peyzaj değişimine neden olan/olabilecek baskı unsurları saptanmıştır. Bu unsurların belirlenmesinde arazi çalışmaları, yöre halkıyla yapılan görüşmeler, alana ilişkin farklı meslek disiplinleri ve kurumlar tarafından yapılan çalışmalar ile özellikle Uluabat Gölü Yönetim Planı (Anonim 2007), yol gösterici olmuştur. 
Çizelge 2. Peyzaj karakter alanları üzerindeki baskı unsurları

\begin{tabular}{ll}
\hline PEYZAJ KARAKTER ALANLARI & BASKI UNSURLARI \\
\hline Çatalağıl Tarımsal Yoğunluklu PKA & $\begin{array}{l}\text { Tarımsal amaçlı gübre ve ilaç kullanımı } \\
\text { Kırsal yerleşim karakterine uygun olmayan yapı, malzeme, donatı vb. kullanımı }\end{array}$ \\
\hline \multirow{3}{*}{ Uluabat Sulak Alan PKA } & $\begin{array}{l}\text { Endüstriyel ve evsel atık deşarjları ve tarım kaynaklı kimyasalların göle ulaşması } \\
\text { Havza içerisinde madencilik faaliyetlerinin su kalitesi üzerindeki olumsuz etkisi } \\
\text { Göl çevresinde yer alan tarımsal alanlarda kullanılmak üzere, gölden su çekilmesi } \\
\text { Balıklar ve kuşlar üzerindeki av baskısı }\end{array}$ \\
\hline Dorak Mevkii Fundalık-Ormanlık & Uluabat HES \\
Yoğunluklu PKA & Madencilik faaliyetleri \\
\hline Canbaz Fundalık Yoğunluklu PKA & Kırsal yerleşim karakterine uygun olmayan yapı, malzeme, donatı vb. kullanımı \\
\hline Akçalar Kentsel- Endüstriyel & Endüstri kuruluşları amacıyla bitki örtüsünün tahrip edilmesi \\
Yoğunluklu PKA & Kentsel karakter gösteren yapılarda yaşanan artış \\
\hline Uluabat Adalar PKA & Kırsal yerleşim karakterine uygun olmayan yapı, malzeme, donatı vb. kullanımı \\
\hline Gölyazı Tarihsel-Arkeolojik & - \\
Yoğunluklu PKA & Tescilli sivil mimari yapılar ile arkeolojik alanların tahrip edilmesi \\
\hline
\end{tabular}

Sulak alanlarla kırsal dokunun iç içe geçtiği çalışma alanı içerisinde yer alan 22 yerleşim alanı 5216 sayılı Büyükşehir Belediyesi yasası ile köy tüzel kişiliğinden mahalle statüsüne geçmiştir. 2012 yılında yapılan bu değişiklik sonucunda köy tüzel kişiliklerinin sona erdirilmesi ve bu köylerin belediyelere bağlı mahalleler olarak kabul edilmesiyle, belediyeler yoluyla bu alanlara donatı elemanları, yol vb. bir takım hizmetler götürülmektedir. Arazi çalışmaları sonucunda bu alanlarda kullanılan yapısal elemanlar ile donatı elemanlarının çoğunlukla alanın kimliğine uygun olmadığı, kırsal yerleşimin özgün peyzaj değeri üzerinde negatif etki oluşturduğu gözlemlenmiştir.

Çalışma alanında Gölyazı Tarihsel-Arkeolojik Yoğunluklu PKA olarak belirlenen Gölyazı yerleşim alanı ve çevresinde, kırsal yerleşim tipini yansıtan pek çok tescilli sivil mimari yapı tahrip olmuş durumda ve bir kısmı da yıkılma tehdidi ile karşı karşıyadır.

Çatalağıl Tarımsal Yoğunluklu PKA olarak belirlenen alanın arazi kabiliyet sınıflarına bakıldığında, yoğunluklu olarak I. II. ve III. sınıf arazilerden oluştuğu belirlenmiştir. Tarımsal verimlilikleri yüksek olan bu alanlarda kimyasal ilaç ve gübre kullanımı geçirimli toprak katmanları, kayaçlar ve yüzeysel akışlarla Uluabat Gölü'ne ulaşmakta (Anonim 2007), gölün su kalitesi ve göl ekosistemi üzerinde baskı oluşturmaktadır.
Uluabat Sulak Alan PKA olarak belirlenen alan; Uluabat Gölü, gölü besleyen ana kaynak olan Mustafakemalpaşa Çayı ve gölden su çıkışını sağlayan Uluabat Deresi'ni kapsamaktadır. Biyolojik çeşitlilik ve üretkenlik açısından büyük önem taşıyan, barındırdığı balık tür ve çeşitliliği, özellikle su kuşları açısından uluslararası öneme sahip olan Uluabat Gölü üzerinde pek çok baskı unsuru bulunmaktadır. Bu baskı unsurlarının bir kısmı çalışma alanı içerisinde oluştuğu gibi bazıları da havza bazındaki yanlış uygulama ve kullanımlardan kaynaklanmaktadır. Endüstriyel ve evsel atık deşarjları ve tarım kaynaklı kimyasalların göle ulaşması, havza içerisinde madencilik faaliyetlerinin su kalitesi üzerindeki olumsuz etkisi, göl çevresinde yer alan tarımsal alanlarda kullanılmak üzere, gölden su çekilmesi mevcut su kalitesi ve potansiyeli üzerinde baskı oluşturmaktadır. Göl ve çevresinde sulak alan ekosistemi açısından görülen olumsuzluklardan biri de balıklar ve kuşlar üzerindeki av baskısıdır (Anonim 2007, Anonim 2018).

Canbaz Fundalık Yoğunluklu PKA için en büyük tehdit tarım alanı açmak için bitki örtüsünün tahrip edilmesi olarak tespit edilmiştir.

Akçalar Kentsel-Endüstriyel Baskı Yoğunluklu PKA olarak belirlenen alan, Akçalar yerleşim alanı ve çevresini kapsamaktadır. Bursa ilinin batıya doğru ilerleyen kentsel etkisi ve çalışma alanına yakın bir alanda bulunan sanayi baskısı özellikle Akçalar yerleşim alanı çevresinde gün 
geçtikçe artmaktadır. Bu etki özellikle çalışma alanı sınırına kadar ulaşan apartman blokları ve sanayi tesisleri ile kendini açıkça göstermektedir. Akçalar mevkii yoğunluklu olarak II. ve III. sınıf tarım arazilerinin bulunduğu tarımsal faaliyetlerin yaygın olarak yapıldığı bir alan olup, yanlıs alan kullanımları sebebiyle nitelikli topraklarını kaybetmekte, bu durum alanda peyzaj parçalanmalarına neden olmaktadır.

Dorak Mevkii Fundalık-Ormanlık Yoğunluklu PKA olarak belirlenen alan, çalışma alanı içerisinde en yüksek eğim derecesine sahip ve erozyon potansiyeli yüksek alanları kapsamaktadır. Alan içerisinde yer alan Uluabat HES'e ait su tünellerinin geçtiği hat ile alan içerisinde yürütülmekte olan madencilik faaliyetleri, bitki örtüsünde tahribata yol açarak erozyon riskini arttırmakta ve alan peyzajı üzerinde ekolojik ve görsel bozulmalara yol açmaktadır.

\section{TARTIŞMA VE SONUÇ}

APS gereğince, yerel ölçekte Uluabat Gölü ve çevresinde, peyzajların korunması, planlama ve yönetiminde günümüzde kullanılan en önemli araçlardan biri ve peyzaj karakter değerlendirme yönteminin bir aşaması olan, peyzaj karakter analizi yoluyla, peyzaj karakter tip ve alanları belirlenmiştir. Çalışma alanının sınırlarının belirlenmesinde Ramsar çerçevesince belirlenen Uluabat Gölü tampon bölge sınırları dikkate alınmıştır. Büro ve arazi çalışmaları olarak iki eşgüdümlü süreç şeklinde ilerleyen çalışmada, büro çalışmaları kapsamında veri katmanları CBS ortamında sayısallaştırımış ve veri tabanlarına aktarılmıştır. Jellema et al. (2009), Uzun ve ark. (2012), Şahin ve ark. (2014), Atik ve ark. (2015), Kusumoarto et al. (2017), Tırnakçı ve Özer (2018), Turgut ve Tırnakçı (2020)'da çalışmalarında CBS tekniklerinden yararlanmışlardır.

Peyzajların tanımlanması ve peyzaj karakter tespitine yönelik çalışmalar farklı ölçeklerde gerçekleştirilebilmektedir. Yerel, bölgesel ve ulusal ölçeklerde gerçekleştirilen çalışmalarda gerek ölçeğin etkisi gerekse alanın niteliğine göre farklı veri katmanlarıyla çalışılabilmektedir. Tırnakçı ve Özer (2018), Şavşat ilçesinde gerçekleştirdiği peyzaj sınıflandırma çalışmasında; iklim, topografya, büyük toprak grupları, arazi örtüsü ve jeoloji katmanlarını kullanırken, Atik ve ark. (2015), Side örneğinde; topografya, toprak, arazi sınıfları, ana materyal, vejetasyon ve arazi kullanım şekilleri veri katmanlarından yaralanmışlar, iklim verisini peyzajların sınıflandırııması aşamasında bir katman olarak kullanmamışlardır. Yerel ölçekte gerçekleştirilen bu çalışmada topografya, jeoloji, toprak, vejetasyon ve arazi kullanım şekilleri katmanları kullanılmışır. İklim peyzajlar üzerinde etkili ve belirleyici bir faktör olmasına rağmen, çalışma ölçeği de dikkate alınarak, çalışma alanı içerisinde belirgin değişkenlikler göstermemesi sebebiyle kullanılmamıştır.

Peyzaj karakter tiplerinin belirlenmesinde doğal peyzaj bileşenleri yanında kültürel peyzaja ilişkin özellikler dikkate alınmıştır. Kültürel peyzaja ilişkin özellikler ile peyzajın görsel algısının anlaşılması, peyzaj karakter alanlarının belirlenmesi, peyzaj karakter alanları üzerindeki baskı unsurlarının saptanması ve sürdürülebilir alan kullanımına yönelik senaryoların geliştirilmesine katkı sağlaması amacıyla arazi çalışmaları gerçekleştirilmiştir. Uzun ve ark. (2012), Şahin ve ark. (2014), Atik ve ark. (2015), Tırnakçı ve Özer (2018)'de yaptıkları peyzaj karakter çalışmalarında benzer şekilde arazi çalışmaları yürütmüşlerdir.

Demir ve Demirel (2016) Trabzon Meryemana Vadisi Havzası'nda gerçekleştirdikleri peyzaj karakter değerlendirmesi sonucunda 84 peyzaj karakter tipi ve 10 peyzaj karakter alanı, Tırnakçı ve Özer (2018) Artvin ili Şavşat ilçesinde 854 peyzaj karakter tipi ve 13 peyzaj karakter alanı, Atik ve ark. (2015) ise Antalya ili Side ilçesinde gerçekleştirdikleri çalışma sonucunda 22 peyzaj karakter tipi ve 7 peyzaj karakter alanı tespit etmişlerdir. Yerel düzeyde gerçekleştirilen bu çalışma sonucunda da 229 adet peyzaj karakter tipi tespit edilmiş ve 7 adet peyzaj karakter alanı belirlenmiştir.

Çalışma sonucunda belirlenen peyzaj karakter alanlarının belirlenmesinde etkili olan ve tutarlııkları yüksek olan bileşenler; arazi kullanım şekilleri, vejetasyon, toprak ve topografik yapı olarak saptanmıştır. Çalışma alanı içerisinde, jeolojik yapının tutarlılığı ise karakter tiplerini oluşturan diğer bileşenlere göre daha zayıftır.

Peyzaj neredeyse sürekli bir değişim içindedir. Bu değişim, etkileşim içerisinde olan doğal ve karmaşık süreçler ile 
insan etkinlikleri sonucunda meydana gelmektedir (Aksu 2014). Çalışma alanı içerisinde de çoğunlukla antropojen etkilerden kaynaklanan peyzajın yapı ve fonksiyonunu etkileyerek, peyzaj karakter alanları üzerinde peyzaj değişimine neden olan/olabilecek baskı unsurları saptanmıştır. Bu unsurların belirlenmesinde arazi çalışmaları, yöre halkıyla yapılan görüşmeler, alana ilişkin farklı meslek disiplinleri ve kurumlar tarafından yapılan çalışmalar ile özellikle Uluabat Gölü Yönetim Planı (Anonim 2007), yol gösterici olmuştur. Sonuç olarak, mevcut durum ve elde edilen veriler doğrultusunda, alanın sürdürülebilir kullanımı desteklemek amacıyla bir takım önerilere yer verilmiştir.

Arazi çalışmaları sonucunda çalışma alanı içerisinde yer alan 22 yerleşim alanında kullanılan yapısal elemanlar ile donatı elemanlarının çoğunlukla alanın kimliğine uygun olmadığı, kırsal yerleşimin özgün peyzaj değeri üzerinde negatif etki oluşturduğu gözlemlenmiştir. Bu yüzden kullanılacak yapısal elemanların gerek malzeme gerekse tasarım itibariyle alanın kimliğine uygun olarak seçilmesi önem taşımaktadır.

Çalışma alanında ve özellikle Gölyazı Tarihsel-Arkeolojik Yoğunluklu PKA olarak belirlenen Gölyazı yerleşim alanı ve çevresinde, alanın kırsal karakterini yansıtan yerel mimari elemanlar mutlak surette korunmalı, kısmen zarar görmüş ya da yıkılma riski ile karşı karşıya kalan yapılar restore edilerek tekrar kullanıma kazandırılmalıdır.

Çatalağıl Tarımsal Yoğunluklu PKA olarak belirlenen alan içerisinde tarımsal faaliyetler sırasında kullanılan kimyasal gübre ve ilaç kullanımının sınırlandırılması, yöre halkının bu konuda bilinçlendirilmesi ve kullanımın denetlenmesi önerilmektedir.

Uluabat Sulak Alan PKA üzerindeki baskıların önlenmesi/azaltılması amacıyla; endüstriyel ve evsel atık deşarjlarının göle ulaşmasının engellenmesi, gölü çevreleyen tarımsal alanlarda kimyasal ilaç, gübre kullanımının azaltılması/denetlenmesi, havza içerisindeki madencilik faaliyetlerinin denetlenmesi, gölden sulama amaçlı su çekiminin azaltılması/sınırlandırılması, gölün taşkın alanı içerisinde sulak alan ekosistemine etki edebilecek tarımsal faaliyetlerin denetlenmesi, bilinçsiz saz kesimi, aşırı ve yasa dışı balık avcııı̆ı, tür aşılaması yapılarak göl ekolojisine müdahale edilmesinin önüne geçilmesi gerekmektedir.

Canbaz Fundalık Yoğunluklu PKA içerisinde bulunan bitki örtüsünün korunması, tarım alanı açmak amacıyla bitki örtüsünün tahrip edilmesinin engellenmesi gerekmektedir.

Akçalar Kentsel-Endüstriyel Baskı Yoğunluklu PKA olarak belirlenen alanda gerek alan içerisinde bulunan tarımsal nitelikli toprakların, gerekse göl ekosistemi ve alanın Ramsar niteliğinin korunması amacıyla endüstri kuruluşları ve yapılaşmanın Ramsar sınırı gözetilerek denetlenmesi, yeni yapı ve kuruluşların önüne geçilmesi gerekmektedir. Bursa Büyükşehir Belediyesi İmar ve Şehircilik Dairesi Başkanlığı Şehir Planlama Şube Müdürlüğü tarafından 2013 yılında hazırlanan 2030 yılı 1/100000 ölçekli Bursa il çevre düzeni planında Akçalar mevkiinde bulunan sanayi alanı, "taşınacak sanayi" olarak belirlenmiştir. Alanda sürdürülebilir kullanımın sağlanması, alan üzerindeki sanayi kaynaklı baskının azaltılması doğrultusunda, daha fazla bozunuma yol açmadan plan kararlarının ivedilikle uygulanması gerekli görülmektedir. Alanda meydana gelen bozunumun etkilerinin azaltılması için peyzaj onarım faaliyetlerinin yürütülmesi önem taşımaktadır.

Dorak Mevkii Fundalık-Ormanlık Yoğunluklu PKA olarak belirlenen alan içerisinde bulunan Uluabat HES'den çıkan suyun göle giriş yaptığı alanda daha önce durgun olan su yüzeyinde oluşturacağı hareketlilik ve su debisinde oluşacak artışların, durgun su yüzeyinde yaşama, üreme, beslenme faaliyeti sürdüren canlılar ve özellikle su kuşları için uzun vadede oluşturacağı etkilerin araştırılması göl ekosisteminin korunması açısından önemli görülmektedir. Çalışma alanı içerisinde en yüksek eğim derecesine sahip ve erozyon potansiyeli yüksek alanları kapsamakta olan alanda, gerek Uluabat HES'in inşa aşamasından itibaren su tünellerinin geçtiği hat boyunca, gerekse madencilik faaliyetlerinin yürütüldüğü OnaçDorak yerleşimleri yakınlarında, doğal bitki örtüsünün tahrip oluğu tüm alanlarda, peyzaj onarım faaliyetlerinin yürütülmesi gerekmektedir. 


\section{TEŞEKKÜR}

Bu çalışma, 'Uluabat Gölü ve Çevresinin Peyzaj Karakter Analizi' adlı doktora tezinden oluşturulmuştur.

\section{KAYNAKLAR}

Aksu G A (2014) Bütüncül (Holistik) Peyzaj Planlama Yaklaşımı, İstanbul Ticaret Üniversitesi Fen Bilimleri Dergisi, Yıl:13, Sayı:26, 21-34

Anonim (2007) Uluabat Gölü Sulak Alan Yönetim Planı, T.C. Çevre ve Orman Bakanlığı, Doğa Koruma ve Milli Parklar Genel Müdürlüğü Sulak Alanlar Şube Müdürlüğü

Anonim (2011) T.C. Bursa Valiliği 2011 Yılı il Çevre Durum Raporu s:128-136, Çevre ve Şehircilik İ Müdürlüğü, Bursa

Anonim (2013) Türkiye'nin Önemli Sulak Alanları- Ramsar Alanlarımız, Orman ve Su İşleri Bakanlığı Doğa Koruma ve Milli Parklar Genel Müdürlüğü, Hassas Alanlar Dairesi Başkanlığı, Sulak Alanlar Şube Müdürlüğü, Ankara

Anonim

http://www.resmigazete.gov.tr/eskiler/2003/07/20030727.htm (22.08.2017)

Anonim (2018) http://www.turkiyesulakalanlari.com (21.02.2018)

Anonymous (2006) Ningaloo Coast Visual Landscape Study, Blowholes, Red Bluff, Gnaraloo Bay, Warroora and Coral Bay, Ningaloo Sustainable Development Office, $49 \mathrm{pp}$

Anonymous (2016) European Landscape Conventionand Reference Documents https://rm.coe.int/CoERMPublicCommonSearchServices/Display DCTMContent?documet Id $=09000016802 \mathrm{f} 80 \mathrm{c} 6$ (03.02.2016)

Anonymous (2018) www.nature.scot (20.02.2018)

Anonymous (2018a) http://www.ramsar.org (13.01.2018)

Atik M, ışıkı R C, Ortaçesme V, Yıldırım E (2015) Definition of Landscape Character Areas and Types in Side Region, AntalyaTurkey with Regard to Land Use Planning, Land UsePolicy 44 (2015) 90-100

Çetinkaya G, Uzun O (2014) Peyzaj Planlama, Birsen Yayın Dağıtım Ltd. Şti, İstanbul

Demir S, Demirel Ö (2016) Korunan Havzalarda Peyzaj Değişimi ve Peyzaj Karakter Analizi ile Peyzaj Planlama Yaklaşımı: Meryemana Vadisi Örneği, Trabzon, İnönü Üniversitesi Sanat ve Tasarım Dergisi, Cilt 6, No. 13, s:155-174

Görmüş S (2012) Korunan Alanlarda Peyzaj Karakter Analizi: Kastamonu- Bartın Küre Dağları Milli Parkı Örneği. Doktora Tezi, A.Ü. Fen Bilimleri Enstitüsü, Ankara

Görmüş S, Oğuz D (2013) Kırsal Yerleşim ve Korunan Alan Arasındaki Etkileşimin Değerlendirilmesinde Peyzaj Karakter Analizinin Rolü: Kapısuyu Havzası Örneği, Tarım Bilimleri Dergisi 19, s:310-322

Herlin I S (2016) Exploring the National Contextsand Cultural Ideas that Preceded the Landscape Character Assessment Method in England, Landscape Research, 41:2, 175-185, DOI: 10.1080/01426397.2015.1135317
Hızlı Ş, Ceran Y, Meriç B T (2013) T.C. Orman ve Su İşleri Bakanlığı Doğa Koruma ve Milli Parklar Genel Müdürlüğü, Sulak Alanlar Kitabı, s: 81-96. Ankara

Jellema A, Stobbelaar D J, Groot J C J, Rossing W A H (2009) Landscape Character Assessment Using Region Growing Techniques in Geographical Information Systems, Journal of Environmental Management 90 (2009) Page:161-174

Kim K H, Pauleit S (2007) Landscape Character, Biodiversity and Land Use Planning: The Case of Kwangju City Region, South Korea, Land Use Policy 24 (2007) 264-274

Koç A (2017) Yukarı Aras Havzası Örneğinde Peyzaj Karakter Analizi. Doktora Tezi, A.Ü. Fen Bilimleri Enstitüsü, Erzurum

Kusumoarto A, Gunawan A, Machfud Hikmat A (2017) Landscape Character of Pongkor Mining Ecotourism Area, 2nd International Symposium for Sustainable Landscape Development, IOP Conf. Series: Earth and Environmental Science 91 (2017) 012028

Martin J (2006) Landscape Character Assessment (LCA) in Ireland: Baselina Audit and Evaluation. Heritage Council. ISBN 978-1906304-01-0, Dublin

Scott A (2002) Assessing Public Perception of Landscape: The LANDMAP Experience, Landscape Research, 27:3, 271-295, DOI: 10.1080/01426390220149520

Swanwick C (2002) Landscape Character Assessment.Guidance for England and Scotland, Cheltenham (UK); Edinburg: The Countryside Agency; Scottish National Heritage

Şahin Ş, Perçin H, Kurum E, Uzun O, Bilgili B C (2014) Bölge - Alt Bölge (il) Ölçeğinde Peyzaj Karakter Analizi ve Değerlendirmesi Ulusal Teknik Kılavuzu. Müşteri Kurumların T.C. İçişleri Bakanlığı, T.C. Çevre ve Şehircilik Bakanlığı ve T.C. Orman ve Su İşleri Bakanlığı olduğu, T.C. Ankara Üniversitesinin Yürütücü Kuruluş olduğu ve TÜBiTAK KAMAG 1007 Programı 109G074 No'lu PEYZAJ-44 Projesi Çıktısı, 148 Sayfa, Ankara

Tırnakçı A, Özer S (2018) Determining Landscape Character Areas and Types in District Scale: The Sample of Artvin-Savsat-Turkey, Atatürk Üniv. Ziraat Fak. Derg., 49 (1): 53-66

Tudor C (2014) An Approach to Landscape Character Assessment, Natural England

Turgut H, Tırnakçı A (2020) Korunan Alanlarda Peyzaj Karakter Analizi Hatila Vadisi Milli Parkı Örneği, Atatürk Üniversitesi Ziraat Fakültesi Dergisi 51 (1): 8-20

Tülek B, Atik M, (2017) Çankırı, Ilgaz Bölgesi Devrez Alt Havzası Örneğinde Peyzaj Karakter Alanlarının Belirlenmesi, Meditarranean Agricultural Sciences 30(3): 197-204

Uzun O, Illke E F, Çetinkaya G, Erduran F, Açıksöz S (2012) Peyzaj Planlama: Konya İli, Bozkır- Seydişehir- Ahırlı- Yalıhüyük İlçeleri ve Suğla Gölü Mevkii Peyzaj Yönetimi, Koruma ve Planlama Projesi, T.C. Orman ve Su İşleri Bakanlığı Doğa Koruma ve Milli Parklar Genel Müdürlüğü, Ankara

Uzun O (2018) Türkiye Peyzajlarının, Peyzaj Karakter Tip ve Alanlarının Tanımlanması, TÜCAUM 30. Yıl Uluslararası Coğrafya Sempozyumu 3-6 Ekim 2018, Ankara 